\title{
The Neurobiology of Lipid Metabolism in Autism Spectrum Disorders
}

\author{
Javaneh Tamiji b, c Dorota A. Crawford ${ }^{\mathrm{a}-\mathrm{c}}$ \\ a Department of Biology, ${ }^{b}$ School of Kinesiology and Health Science, 'Neuroscience Graduate Diploma Program, \\ York University, Toronto, Ont., Canada
}

\section{Key Words}

Autism • Abnormal fatty acid metabolism • Dietary

supplementation - Genetic defects • Arachidonic acid •

Prostaglandins

\begin{abstract}
Autism is a neurodevelopmental disorder characterized by impairments in communication and reciprocal social interaction, coupled with repetitive behavior, which typically manifests by 3 years of age. Multiple genes and early exposure to environmental factors are the etiological determinants of the disorder that contribute to variable expression of autism-related traits. Increasing evidence indicates that altered fatty acid metabolic pathways may affect proper function of the nervous system and contribute to autism spectrum disorders. This review provides an overview of the reported abnormalities associated with the synthesis of membrane fatty acids in individuals with autism as a result of insufficient dietary supplementation or genetic defects. Moreover, we discuss deficits associated with the release of arachidonic acid from the membrane phospholipids and its subsequent metabolism to bioactive prostaglandins via phospholipase $\mathrm{A}_{2}$-cyclooxygenase biosynthetic pathway in autism spectrum disorders. The existing evidence for the in-
\end{abstract}

volvement of lipid neurobiology in the pathology of neurodevelopmental disorders such as autism is compelling and opens up an interesting possibility for further investigation of this metabolic pathway. C Copyright $\odot 2011$ S. Karger AG, Basel

\section{Introduction}

Autistic disorder is a behaviorally defined neurodevelopmental disorder of childhood characterized by deficits in social interaction, language, communication and repetitive behaviors that manifest in early postnatal life [1]. It belongs to a spectrum of closely related conditions also referred to as autism spectrum disorders (ASDs) that also includes pervasive developmental disorder not otherwise specified, Asperger's syndrome, and childhood disintegrative disorder. The incidence of ASDs has increased significantly over the last decades and is currently 1 in 150, affecting boys four times more often than girls [2, 3]. A strong genetic component is indicated by the high concordance rates in monozygotic twins (70$95 \%)$ versus dizygotic twins (0-23\%) [1, 4-6]. Many genes have been implicated in the etiology of the disorder [4] in addition to the contributing environmental factors [7-

\section{KARGER \\ Fax +4161306 1234 E-Mail karger@karger.ch} www.karger.com
Dr. Dorota Anna Crawford

York University, Faculty of Health

4700 Keele Street, Bethune College, Room 346

Toronto, ON M3J 1P3 (Canada)

Tel. +1 416736 2100, ext. 21058, Fax +1 416736 5774, E-Mail dakc@yorku.ca 


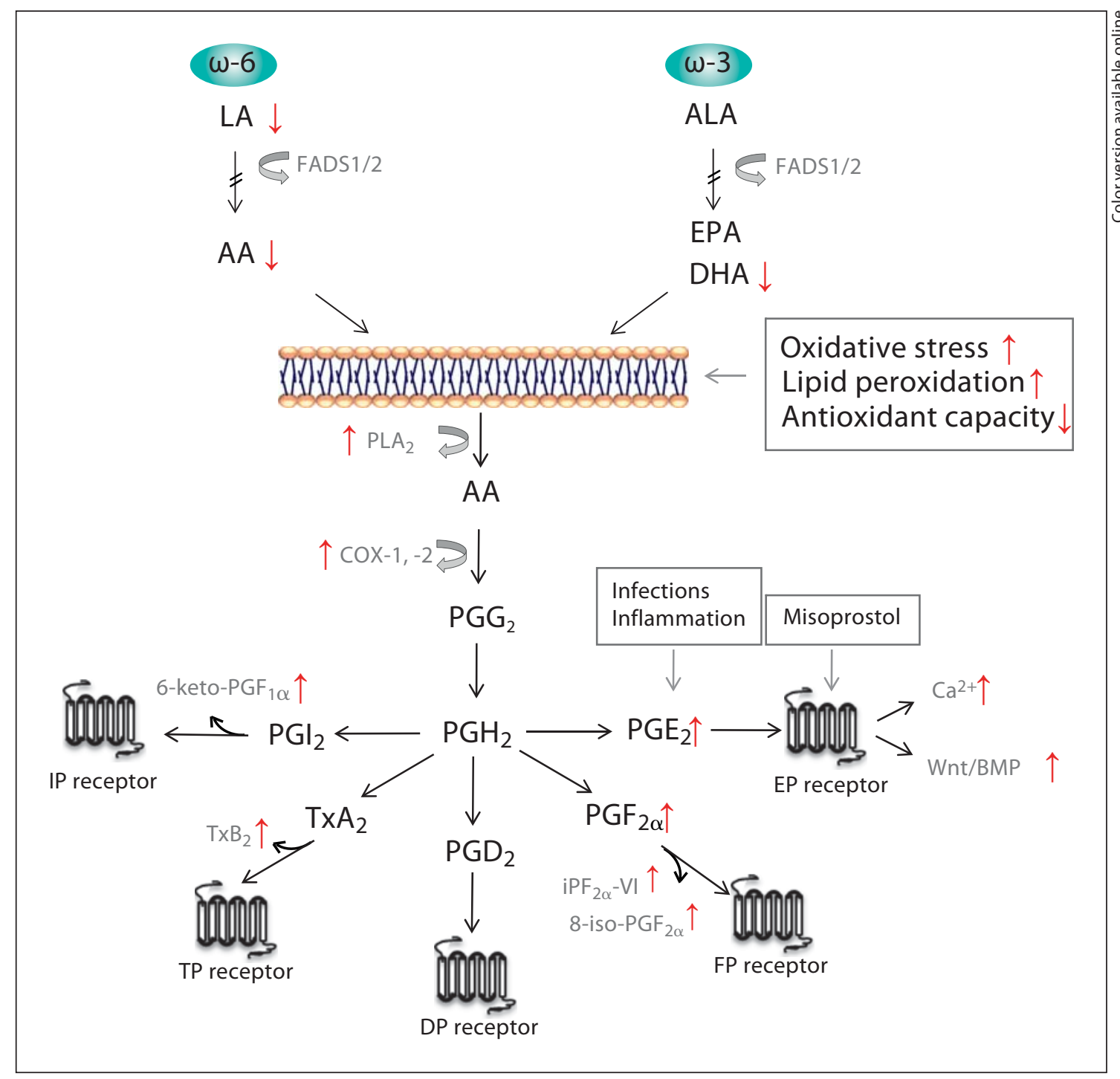

Fig. 1. Schematic diagram illustrating the most common abnormalities in bioactive lipid signaling pathways associated with ASDs.

9], which together determine the broad severity of autism phenotype.

The emerging evidence implies that abnormal fatty acid metabolism may play a contributing role in the pathology of autism [10-12]. Recent literature suggests that fatty acid homeostasis may be altered in autism as a result of insufficient dietary supplementation, genetic defects, function of enzymes involved in their metabolism, or influence of various environmental agents such as infections, inflammation or drugs. This review provides an overview of the proposed candidate sites along the lipid metabolic pathway that have been implicated in the pathology of ASDs.

\section{Lipid Signaling in the Nervous System}

Dry human brain, by weight, is composed of approximately $60 \%$ lipids with over $20 \%$ polyunsaturated fatty acids (PUFAs) [13-15]. PUFAs, predominantly arachidonic acid (AA, 20:4n-6), eicosapentaenoic acid (EPA, 20:5n-3) and docosahexaenoic acid (DHA, 22:6n-3), are major components of the neural cell membrane phospholipids. AA and EPA/DHA are derived from two major types of PUFAs, omega- 6 linoleic acid (LA; 18:2n-6) and omega- $3 \alpha$-linolenic acid (ALA; 18:3n-3), respectively $[16,17]$ (fig. 1). Proper content of omega-3 and ome- 
ga- 6 fatty acids is important for the integrity and proper functioning of the plasma membrane, such as modulation of ion channels, enzymes and receptor activity [18, 19].

DHA and AA play an important role in the nervous system, including retinal development and vision [20,21], neurogenesis and neuronal differentiation [22-24], neural plasticity and signal transduction $[25,26]$, inflammation [27-30], and learning and memory [31-33]. These functions may be regulated by a number of gene products activated by PUFAs during development [34-39]. The plasma membrane phospholipids serve as a supply of second messenger molecules important for normal functioning of the brain $[40,41]$. PUFA such as AA or DHA can also be released from membrane phospholipids by the action of phospholipase $\mathrm{A}_{2}\left(\mathrm{PLA}_{2}\right)$ and subsequently metabolized into various types of bioactive prostanoids (fig. 1). Cyclooxygenase-1 enzyme (COX-1), constitutive form, or cyclooxygenase-2 (COX-2), inducible form, converts $A A$ to the unstable $\mathrm{PGG}_{2}$ intermediate and then to the prostanoid precursor $\mathrm{PGH}_{2}$, which is further metabolized by the prostaglandin (PG) or thromboxane synthases into the major lipid signaling messengers (eicosanoids) such as $\mathrm{PGs}\left(\mathrm{PGE}_{2}, \mathrm{PGF}_{2} \mathrm{\alpha}, \mathrm{PGD}_{2}, \mathrm{PGI}_{2}\right)$, and thromboxane $\mathrm{A}_{2}\left(\mathrm{TxA}_{2}\right)$. The five downstream prostanoids are important signaling molecules that exert their effects through activation of their respective G-protein-coupled receptors called EP (E-prostanoid), FP, DP, IP, and TP receptors [42-44]. The released prostanoids play important roles in normal neural function including sleep induction $\left(\mathrm{PGD}_{2}\right)$, spatial learning, synaptic plasticity and long-term potentiation or inflammation $\left(\mathrm{PGE}_{2}\right)$ $[13,45]$. Of these, $\mathrm{PGE}_{2}$ has gained a considerable attention recently for its involvement in activity-dependent synaptic plasticity via four receptor subtypes EP1-EP4 [46-48].

It is now evident that the brain proper function relies on a balance between the constant supply of the omega-3 and -6 fatty acids in the blood from dietary PUFAs and the release of their metabolites from membrane phospholipids via activation of $\mathrm{PLA}_{2}$ and other key downstream enzymes (fig. 1) [31, 35, 49-52]. Therefore, alterations of the fatty acids metabolic pathway may affect proper function of the nervous system. An association between ASDs and abnormalities at various sites of the lipid metabolic pathway has been reported in various studies and is discussed in the following sections.

\section{Dietary Lipid Imbalances in ASDs}

During the last trimester of pregnancy and the first 2 years of life, human brain undergoes an immense growth during which unesterified omega- 3 and omega- 6 fatty acid content of the grey and white matters increase considerably $[53,54]$. Because of the increased demand, sufficient supply of the essential PUFAs and proper ratio of AA to DHA particularly during early life is critical for proper development and function of the nervous system $[16,31,55-59]$. Both human and animal studies have correlated the presence of AA and DHA during critical period of development to enhanced visual, cognitive and motor functions [23, 60-63]. A link between imbalances in the AA to DHA composition and abnormalities of fatty acid metabolism have been shown to play a role in the pathology of various psychiatric disorders, including attention deficit hyperactivity disorder, dyslexia, dyspraxia, bipolar disorder and schizophrenia [51, 64-71].

Insufficient dietary intake of PUFA during early development and abnormal lipid metabolism have been shown to occur in ASDs as well. Current literature suggests that altered level of omega- 6 fatty acids (i.e. AA) and omega-3 fatty acid (i.e. DHA) may result in an imbalance in the ratio between these PUFAs in the nervous system and potentially contribute to the behavioral outcomes seen in autism. A survey study reported that children who were not breastfed or fed on infant formula not supplemented with PUFAs were significantly more likely to develop autism [72]. Altered level of LA, DHA and AA and significantly higher AA:DHA ratio was reported in the blood samples (plasma and red blood cells) of autism patients compared to the control group [15]. Other studies have reported a significant reduction in AA and DHA levels in the plasma of autistic children compared to the levels in controls [73-75]. Decreased level of DHA and subsequently higher AA:DHA ratio were also detected in the red blood cells of children with regressive autism and Asperger's syndrome compared to typically developing controls [14, 76]. Sliwinski et al. [77] observed an increase in the plasma omega-3 PUFAs, in particular DHA and an increase in the total omega- 3 and omega- 6 PUFA ratio in high-functioning males with autism compared to healthy controls. Moreover, other lipid biomarkers such as saturated and polyunsaturated very long-chain fatty acidcontaining phosphatidyl-ethanolamines and DHA-containing ethanolamine plasmalogens (PlsEtns) were also elevated in the plasma of subjects with autism [78].

The link between altered brain fatty acid metabolism and the occurrence of autism-like behavior has been also 
demonstrated in animal models. For example, various studies reported that exposure to environmental agents such as propionic acid (PPA), derived from enteric bacteria or diet, may result in the appearance of autism-like behavior in rodents as a result of altered composition of brain phospholipids [79-81]. Intraventricular infusions of PPA, reduction in total monounsaturated fatty acids, omega- 6 fatty acids and PlsEtns, decreased omega-6/ omega-3 ratio, and increased level of total saturated fatty acids, which is consistent with reports observed in the blood of autistic patients $[79,82]$.

Although there are some differences between the reported results, overall these studies show that imbalances in omega- 3 and omega- 6 fatty acids exist in patients with autism and likely contribute to the behavioral outcomes in some subsets of autistic patients. Interestingly, administration of supplements containing omega- 3 and omega- 6 fatty acids resulted in increased level of these fatty acids in the blood, reduced AA:DHA ratio and improvements in several behavioral domains such as eye contact, concentration and motor skills in individuals with autism [15]. Supplementation of omega-3 fatty acids has been shown to be effective in ameliorating hyperactivity associated with autism [83]. Moreover, improvements in behavior and significant reduction in the elevated DHA and very long-chain fatty acid biomarker level were observed in autistic subjects taking carnitine supplements [78]. Previous studies have shown that carnitine, normally required for fatty acid metabolism, is significantly reduced in some children with autism [84].

The molecular mechanisms for the altered PUFA level in autistic children are not well understood. Some potential causes have been proposed, including insufficient dietary intake of PUFA precursors, defects associated with enzymes involved in the conversion of dietary PUFAs into longer and highly unsaturated derivatives or deficiency in the process of incorporation of PUFAs into membrane phospholipids [73]. It has been suggested that fatty acid desaturase 1 (FADS1, delta-5-desaturase) and fatty acid desaturase 2 (FADS2, delta-6-desaturase), the rate-limiting enzymes in the metabolism of LA and ALA (precursors of AA and DHA), could contribute to lipid imbalances observed in autism. Interestingly, FADS1 and FADS2 are located in a close proximity to a linkage peak for autism on chromosome 11q22 [85]. This is an appealing possibility since recent studies have found an association between genetic variants in FADS1/FADS2 and attention deficit hyperactivity disorder [86] and other complex diseases, including bipolar disorder or atopic syndrome $[87,88]$.

The Neurobiology of Lipid Metabolism in Autism Spectrum Disorders

\section{Abnormalities in PG Metabolic Pathway Associated with ASDs}

\section{Phospholipase $\mathrm{A}_{2}$}

$\mathrm{PLA}_{2}$ is an enzyme involved in the maintenance of membrane phospholipids. There are three major types of $\mathrm{PLA}_{2}$ enzyme: the calcium-dependent group IV cytosolic $\mathrm{PLA}_{2}$, the group II secretory PLA $\mathrm{PA}_{2}$ and the group VI calcium-independent PLA $2[40,89]$. PLA $_{2}$ releases AA from the $s n-2$ position of phospholipids, a precursor of key lipid mediators such as PGs (fig. 1) [89, 90], and it has been shown to play a key role in neuronal plasticity [91]. Stimulation with various neurotransmitters such as glutamate [92], $N$-methyl-D-aspartic acid [93], or $\alpha$-amino3-hydroxy-5-methyl-4-isoxazole PPA [94] can lead to $\mathrm{PLA}_{2}$ activation and release of AA and its metabolites. Additionally, AA and DHA can be released in the presence of stimuli such as cytokines during the inflammatory response [95].

Elevated level of $\mathrm{PLA}_{2}$ in red blood cells has been associated with neuropsychiatric disorders such as schizophrenia, depression, bipolar disorder, dyslexia and autism $[14,96]$. A substantial amount of evidence has accumulated on elevated plasma levels of $\mathrm{PLA}_{2}$ in schizophrenia patients compared to healthy controls [14, 97-99]. Three single nucleotide polymorphisms in the gene encoding for cytosolic $\mathrm{PLA}_{2}$ have been linked to schizophrenia and found to play a possible role in the etiology of this disorder [100-103]. Interestingly, the genes encoding human calcium-independent $\mathrm{PLA}_{2}$ and secretory $\mathrm{PLA}_{2}$ map to regions on chromosome 8q23-24 and $7 \mathrm{q} 31$, respectively $[104,105]$, which have been previously linked to autism [106-108]. It has been suggested that the altered levels of AA and DHA in individuals with autism described above may be attributed to abnormalities in $\mathrm{PLA}_{2}$. Indeed, significantly increased activity of type IV $\mathrm{PLA}_{2}$ has been reported in red blood cells of patients with autism and Asperger's syndrome compared to the controls, strengthening the hypothesis that abnormal lipid metabolism occurs in autism [14, 109]. It has been proposed that the observed increased $\mathrm{PLA}_{2}$ activity in individuals with autism may be the cause for elevated breakdown of PUFAs and their subsequent reduced incorporation into membrane phospholipids. Overall, the literature suggests a link between abnormalities in $\mathrm{PLA}_{2}$ enzymes and some psychiatric disorders including autism spectrum, which substantiates the importance of downstream lipid signaling molecules in the proper functioning of the nervous system. 


\section{COX Enzymes}

COX is the key enzyme that converts AA to PGs [45] (fig. 1). COX-1 mediates 'housekeeping' functions in most tissues, and COX-2 is the inducible form and participates in the inflammatory responses. Growing evidence shows that COX-2 plays an important role in the nervous system via production of downstream signaling molecules such as PGs [41]. The COX-2/PGE2 pathway plays an important function in synaptic plasticity and refining of mature neuronal connections [110-112] in addition to its role during inflammatory response and oxidative stress [113-115]. It has been shown that selective COX-2 inhibitors can cause a reduction in long-term potentiation, which in turn can be reversed by addition of exogenous $\mathrm{PGE}_{2}$, but not $\mathrm{PGD}_{2}$ or $\mathrm{PGF}_{2} \alpha$, indicating an important role for COX-2 and its downstream metabolites in the nervous system [112]. Interestingly, it has been shown that $\mathrm{PGE}_{2}$ can stimulate glutamate release from astrocytes and modulate the activity of neighboring neurons [116-118].

Altered COX-2 level has been reported in neurological disorders, such as stroke and Alzheimer's disease or psychiatric disorders, indicating that it may contribute to abnormalities in the nervous system [119-122]. The evidence for the involvement of the COX-2/PGE 2 pathway in ASDs is now emerging. COX-2 activity and production of PGs is normally induced by cytokines or proinflammatory molecules [119] and altered immune responses have been reported in cases of ASD [123, 124], suggesting the possible involvement of COX-2 in some cases of autism. More recently, an association between PTGS2 polymorphism (the gene encoding COX-2 enzyme) and ASDs has been reported [125]. Furthermore, altered laminar pattern of COX-2 immunoreactivity in the cortex has been shown in individuals with Rett syndrome, a form of ASD, further strengthening the evidence for the involvement of abnormal COX-2 signaling in the pathology of the autism disorders [126].

\section{$P G E_{2}$ Signaling Pathway and Early Development}

$\mathrm{PGE}_{2}$ is a signaling molecule that diffuses rapidly through the membranes and exerts its diverse effects in the nervous system through four G-protein coupled EP receptors: EP1, EP2, EP3 and EP4 [127-129]. The role of $\mathrm{PGE}_{2}$ in mediating physiologically important functions such as modulation of pain, fever, and inflammatory response in the nervous system is well established [130135]. In addition, the involvement of $\mathrm{PGE}_{2}$ signaling in early development including formation of dendritic spines and neuronal plasticity is also emerging $[112,136]$.
Clinical studies reported that prenatal exposure to the drug misoprostol, a prostaglandin type $\mathrm{E}$ analogue, during the first trimester of pregnancy may contribute to neurodevelopmental defects, including Möbius syndrome, a disorder associated with damage to the sixth and seventh cranial nerves, and ASD [137-144]. This indicates that early embryonic exposure to misoprostol may interfere with the $\mathrm{PGE}_{2}$ signaling and have neurotoxic effects on the developing nervous system. Misoprostol is commonly used as a drug in treating stomach ulcers [145], inducing labor [146] or in medical termination of pregnancy [147]. It has been suggested that the embryo is most vulnerable to misoprostol during early stages of pregnancy, 5-6 weeks after fertilization [148]. Some evidence for the molecular effects of misoprostol action on cell function comes from a recent study on Neuro-2a cells. Misoprostol and $\mathrm{PGE}_{2}$ can elevate intracellular calcium level and the amplitude of calcium fluctuations in growth cones, as well as reduce the number and length of the neurite extensions in a dose-dependent manner via EP receptors $[149,150]$. Interestingly, it has been previously shown that dysfunction in calcium regulation may play a role in the pathogenesis of ASDs [151-157]. These studies suggest that misoprostol may contribute to the neurotoxic effects on neuronal development and communication via $\mathrm{PGE}_{2}$ pathway.

Various studies have reported a crosstalk between $\mathrm{COX}-2 / \mathrm{PGE}_{2}$ signaling pathway and morphogen molecules such as Wnt (wingless) or BMPs (bone morphogenetic proteins) and their cooperative regulation in neuronal differentiation [158-163]. This is interesting because Wnt and BMP signaling normally play a key role in early patterning of the nervous system, neural tube formation, neuronal migration and differentiation, as well as synaptogenesis, synaptic plasticity and synaptic differentiation [164-168]. Wnt-2, one of many wingless genes regulating cell fate and patterning during early neuronal development [169], is located in the region of chromosome 7q3133 linked to autism [108, 170, 171]. Interestingly, mutations and polymorphism in Wnt-2 were found in individuals with autism and severe language abnormalities, respectively, indicating its potential involvement in the pathogenesis of ASDs [172]. Wnt signaling pathways also play an important role in axon guidance and synapse formation, which involves the release of calcium from intracellular stores for growth cone remodeling and synaptogenesis [173]. $\mathrm{PGE}_{2}$ - or misoprostol-induced alteration of calcium fluctuation in growth cones as shown by Tamiji and Crawford $[174,175]$ may potentially interfere with Wnt signaling pathway and affect differentiation. It has 
been shown that $\mathrm{Ca}^{2+}$ signaling triggered by neuronal activity mediates synthesis and secretion of CREB-dependent transcription Wnt-2 and contributes to proper dendritic outgrowth and branching, suggesting the importance of the protein in neuronal development [176]. Moreover, infections associated with the development of gastric cancer can induce the $\mathrm{COX}-2 / \mathrm{PGE}_{2}$ signaling pathway by significantly increasing the level of $\mathrm{PGE}_{2}$ through induction of COX-2 and mPGES-1, membraneassociated PGE synthase-1, and subsequent activation of Wnt and inhibition of BMP signaling pathways [158]. It has also been reported that increased transcription of COX-2 gene and $\mathrm{PGE}_{2}$ level was induced by Wnt signaling pathway in epithelial cells and cancer stem cells, further strengthening the cooperative interaction between these pathways $[160,163,177]$.

The expression of four EP receptors' transcripts (EP1, EP2, EP3 $\beta$ and EP4) significantly increases in the mouse during embryonic day 11-15 (early neurogenesis), indicating that the $\mathrm{PGE}_{2}$ signaling pathway may have an important role during early development [174]. Many brain structures, such as medulla, pons and cerebellum, start to develop at the early stages of the neurogenesis (embryonic day 12) and others, such as, hippocampus, hypothalamus, thalamus and entorhinal cortex that begin developing at around day 15 [178]. The early brain pathology in many of these regions has been reported in autism [179-181]. A direct involvement of COX-2/PGE 2 signaling pathway in the development of these structures still remains to be established.

\section{Contribution of Oxidative Stress and Lipid Peroxidation in the Etiology of ASDs}

Membrane phospholipids are primary targets of oxidative stress, a state in which there is an imbalance between the production of reactive oxygen species and the antioxidant capacity of the cells, including enzymatic and nonenzymatic mechanisms [182]. Reactive oxygen species may induce lipid peroxidation, the oxidative breakdown of lipids, which can disrupt the composition of membrane phospholipids and alter neuronal function $[183,184]$. Presence of double bonds in membrane phospholipids makes them particularly susceptible to oxidative damage $[185,186]$. The brain is considered vulnerable to oxidative stress particularly during its early development because of high lipid content and limited antioxidant capacity making children more susceptible to insults $[187,188]$. Purkinje cells in the cerebellum, for in- stance, are particularly vulnerable to oxidative stress $[189,190]$. Interestingly, significant loss of Purkinje cells accompanied by gliosis was determined in some children with autism $[191,192]$.

Various studies have reported elevation of lipid peroxidation markers accompanied by a reduction in antioxidant enzymes in individuals with autism, suggesting a contribution of altered lipid signaling to the pathogenesis of the disorder $[11,12,193,194]$. Glutathione (GSH) is one of the main antioxidants that protect against lipid peroxidation and oxidative stress in the neurons [195]. Lower levels of reduced GSH (active form) during early postnatal life indicate that the developing brain might be more susceptible to oxidative damage [196]. It has been shown that children with autism have lower levels of the reduced form of GSH, and therefore a decreased ratio of GSH to the oxidized form disulfide GSH. Additionally, a deficiency in methionine and cysteine (precursors in the production of GSH) has been detected in these patients, suggesting that they might be more prone to oxidative stress and at a greater risk of developing brain disorders [12, 78, 197-199]. Several polymorphisms affecting methionine and GSH metabolism have also been reported in cases of autism, suggesting a possibility of genetic influences $[197,200]$.

Interestingly, children with autism exposed to mercury showed significantly decreased level of GSH [201]. Two studies of children in the San Francisco area and Texas found that children living in close proximity to industrial power plant sources of mercury had significantly higher prevalence of autism [202, 203]. Evidence of exposure to mercury due to maternal dental amalgam or vaccination has been also reported in some cases of autism [201]. Pre- or postnatal exposure to toxic metals such as mercury has been shown to contribute to increased oxidative stress and toxic effects on the developing nervous system [204].

Junaid et al. [205] characterized a single nucleotide polymorphism (C419A) in another antioxidant enzyme glyoxalase 1 (Glo1) and showed significantly higher frequency for the A419 allele in patients with autism, suggesting that it might be a predisposing factor in the etiology of the disorder. In addition, a reduced Glol enzyme activity has been also reported in the brain of autism subjects [205]. Interestingly, Glol is located in close proximity to an autism locus on chromosome $6 p$ identified by linkage and association studies, strengthening a possible involvement of Glo1 in autism [206, 207]. Furthermore, the level of malonyldialdehyde, the end products of lipid peroxidation, as well as antioxidant proteins ce- 
ruloplasmin and transferrin, have been shown to be significantly elevated in the plasma or urine samples of autistic children compared to healthy controls $[10,11,194$, 208].

In general, evidence for altered antioxidant capacity and increased oxidative stress in individuals with autism is compelling. Emerging evidence in the recent reports also shows a role played by prostanoid metabolites in the increased oxidative damage in some patients with autism. The levels of a lipid peroxidation biomarker 2,3dinor-thromboxane $\left(\mathrm{Tx}_{2}\right)$, the metabolite of the $\mathrm{TxA}_{2}$ derived from platelets, and 6-ketoprostaglandin $\mathrm{PGF}_{1} \alpha$ (6-keto-PGF $\left.{ }_{1} \alpha\right)$, the metabolite of the endothelium prostacyclin (or $\mathrm{PGI}_{2}$; fig. 1) have been significantly elevated in children with autism [209]. Moreover, 8-isoprostane$\mathrm{F}_{2} \alpha$ (8-iso-PGF $\left.\mathrm{PG}_{2} \alpha\right)$ and isoprostane $\mathrm{F}_{2} \alpha$-VI $\left(\mathrm{iPF}_{2} \alpha\right.$-VI), by-products of prostaglandin $\mathrm{F}_{2} \alpha\left(\mathrm{PGF}_{2} \alpha\right)$ peroxidation produced in a nonenzymatic oxidation of AA (fig. 1), have also been shown to be significantly higher in red blood cells or urine sample of children with autism compared to the healthy controls [10, 209]. Elevated level of $\mathrm{iPF}_{2} \alpha$ was also found in plasma of children with autism [74] and Rett syndrome patients [210]. The increased accumulation of $\mathrm{F}_{2}$-isoprostanes, which normally promotes platelet aggregation and vasoconstriction [211], might explain the altered platelet reactivity in children with autism and may contribute to the vascular abnormalities in these patients [212,213]. Although the effects of the elevated level of PG metabolites in the nervous system need to be elucidated, the reported findings further support the presence of altered lipid biogenesis in ASDs.

\section{Involvement of Immunological Factors}

Emerging evidence suggests that immunological factors might have an effect on brain development through modification of COX-2/PG signaling, and play a role in the pathology of some mental disorders [214-217]. COXderived lipid mediators such as $\mathrm{PGE}_{2}$ or $\mathrm{PGF}_{2} \alpha$ have been shown to be significantly increased following infections [218-220] or inflammations, especially during pregnancy [221-223]. Several clinical studies and case reports have shown possible contributions of viral infections and abnormal immune response in some cases of autism [224]. It has been shown that prenatal and postnatal infections may trigger autoimmune responses in autism [225-227] or stimulate immune responses in the mother or offspring [228-233].
Prenatal and postnatal exposure to viral infections such as measles [234], rubella [235], herpes viruses [236], and cytomegalovirus $[237,238]$ has been associated with autism. Moreover, polyomavirus genome was detected in postmortem brain tissues from individuals with autism, indicating the presence of infection in the brain of these patients [239]. Although the molecular mechanisms by which viral infections contribute to the pathology of autism via $\mathrm{PGE}_{2}$ signaling are still largely unknown and often inconclusive, the animal models provide some indirect evidence that altered immune responses due to infections might contribute to the development of autism. In animal models, pre- and postnatal infections have been shown to lead to immunological changes in offspring, gene alterations in the brain and specific behavioral changes similar to those found in autism spectrum [216, 217, 240-243]. Prenatal exposure of pregnant mice to viral infections also results in increased pyramidal cell density, reduced size of the Purkinje cells of the cerebellum and brain enlargement in the embryos [244]. Similar changes were observed in the brain of individuals with autism $[179,245,246]$.

The immune system, including its inflammatory components, is essential in defense against pathogens. Omega- 6 and omega-3 PUFA eicosanoids play a central role in regulating immune and inflammatory responses [247, 248]. Eicosanoids derived from omega-6 PUFAs (AA) have proinflammatory and immunoactive role, whereas eicosanoids derived from omega-3 PUFAs (EPA and DHA) have anti-inflammatory properties. $\mathrm{PGE}_{2}$, the most abundant eicosanoid produced predominantly from AA, induces cytokine expression [249-252]. A number of case studies provide evidence that dysfunction of the immune system such as generation of antibodies or stimulation of cytokine production may result in pathologies of autism [123]. Elevated levels of plasma immunoglobin classes have been reported in some children with autism, indicating altered susceptibility to infections $[229,253,254]$. Production of proinflammatory cytokines such as tumor necrosis factor- $\alpha$, interleukin- 6 and interferon- $\gamma$, have been elevated in the blood of autistic children compared to healthy controls [255-261]. Immunocytochemical studies using brain tissues from individuals with autism showed that neuroglia-derived macrophage chemoattractant protein-1 and tumor growth factor-1 were the most prevalent cytokines, indicating that immune dysfunction may result in CNS pathology and contribute to the development of autism [262]. Elevated cytokine production can alter CNS function and development [224]. For example, in cultured rat embryonic 
hippocampal neurons interferon- $\gamma$ inhibits dendritic outgrowths, thereby decreasing synaptic formation [263]. Interestingly, reduced dendritic branching has been shown in the hippocampus of autistic patients [264]. Recent studies indicate that gastrointestinal inflammation can also affect CNS via cytokines and contribute to the development of ASDs [265-267]. In animals, intracerebroventricular injections of PPA (the metabolic end product of enteric bacteria) result in astrogliosis in the brain of the animals, suggesting neuroinflammation as a result of activation of CNS innate immune cells [81]. These models of infection in developing animals provide evidence that viral infections and the resulting immune response may alter neuronal development and lead to behavioral abnormalities seen in autism. Further studies are required to provide a direct link for the effect of immunological factors on the function of the COX-2/PG pathway and their contribution to the pathology of autism.

\section{Conclusions}

Autism is a complex neurodevelopmental disorder caused by interaction between genetic and environmental factors. Although autism is behaviorally defined and its biochemical defects are still not well understood, several lines of research support the hypothesis that children with autism show higher rates of in vivo lipid metabolism than healthy controls. The provided evidence shows that impairment at various steps of the lipid metabolic pathways may contribute to the development of autism. These studies collectively suggest that lipid signaling may play an important role in the pre- and postnatal period, and alterations of this pathway can negatively impact the development of the nervous system and lead to autism. Identification of various genetic or environmental factors contributing to deficits in these lipid signaling pathways in individuals with autism will likely be important for understanding the molecular mechanisms of the disorder and the development of novel therapeutic and prevention strategies early in life.

\section{References}

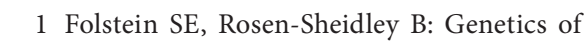
autism: complex aetiology for a heterogeneous disorder. Nat Rev Genet 2001;2:943955.

-2 Fombonne E: Epidemiological surveys of autism and other pervasive developmental disorders: an update. J Autism Dev Disord 2003; 33:365-382

$\checkmark 3$ Inglese MD, Elder JH: Caring for children with autism spectrum disorder. I. Prevalence, etiology, and core features. J Pediatr Nurs 2009;24:41-48.

4 Muhle R, Trentacoste SV, Rapin I: The genetics of autism. Pediatrics 2004;113:e472e486.

$\checkmark 5$ Bailey A, Le Couteur A, Gottesman I, Bolton P, Simonoff E, Yuzda E, Rutter M: Autism as a strongly genetic disorder: evidence from a British twin study. Psychol Med 1995;25:6377.

-6 Hu VW, Frank BC, Heine S, Lee NH, Quackenbush J: Gene expression profiling of lymphoblastoid cell lines from monozygotic twins discordant in severity of autism reveals differential regulation of neurologically relevant genes. BMC Genomics 2006;7:118.

$\checkmark 7$ Keller F, Persico AM: The neurobiological context of autism. Mol Neurobiol 2003;28: $1-22$.

$\checkmark 8$ Herbert MR, Russo JP, Yang S, Roohi J, Blaxill M, Kahler SG, Cremer L, Hatchwell E: Autism and environmental genomics. Neurotoxicology 2006;27:671-684.

\section{-9 Herbert MR: Contributions of the environ- ment and environmentally vulnerable physi- ology to autism spectrum disorders. Curr Opin Neurol 2010;23:103-110.}

10 Ming X, Stein TP, Brimacombe M, Johnson WG, Lambert GH, Wagner GC: Increased excretion of a lipid peroxidation biomarker in autism. Prostaglandins Leukot Essent Fatty Acids 2005;73:379-384.

11 Chauhan A, Chauhan V, Brown WT, Cohen I: Oxidative stress in autism: increased lipid peroxidation and reduced serum levels of ceruloplasmin and transferrin - the antioxidant proteins. Life Sci 2004;75:2539-2549.

-12 James SJ, Cutler P, Melnyk S, Jernigan S, Janak L, Gaylor DW, Neubrander JA: Metabolic biomarkers of increased oxidative stress and impaired methylation capacity in children with autism. Am J Clin Nutr 2004; 80:1611-1617.

13 Tassoni D, Kaur G, Weisinger RS, Sinclair AJ: The role of eicosanoids in the brain. Asia Pac J Clin Nutr 2008;17(suppl 1):220-228.

$>14$ Bell JG, MacKinlay EE, Dick JR, MacDonald DJ, Boyle RM, Glen AC: Essential fatty acids and phospholipase A2 in autistic spectrum disorders. Prostaglandins Leukot Essent Fatty Acids 2004;71:201-204

15 Meguid NA, Atta HM, Gouda AS, Khalil RO: Role of polyunsaturated fatty acids in the management of Egyptian children with autism. Clin Biochem 2008;41:1044-1048.
16 Haag M: Essential fatty acids and the brain. Can J Psychiatry 2003;48:195-203.

$>17$ DeMar JC Jr, Lee HJ, Ma K, Chang L, Bell JM, Rapoport SI, Bazinet RP: Brain elongation of linoleic acid is a negligible source of the arachidonate in brain phospholipids of adult rats. Biochim Biophys Acta 2006; 1761:10501059.

18 Boland LM, Drzewiecki MM, Timoney G, Casey E: Inhibitory effects of polyunsaturated fatty acids on Kv4/KChIP potassium channels. Am j Physiol 2009;296:C1003C1014.

19 Guizy M, David M, Arias C, Zhang L, Cofan M, Ruiz-Gutierrez V, Ros E, Lillo MP, Martens JR, Valenzuela C: Modulation of the atrial specific Kv1.5 channel by the $\mathrm{n}-3$ polyunsaturated fatty acid, alpha-linolenic acid. J Mol Cell Cardiol 2008;44:323-335.

20 Giusto NM, Pasquare SJ, Salvador GA, Castagnet PI, Roque ME, Ilincheta de Boschero MG: Lipid metabolism in vertebrate retinal rod outer segments. Prog Lipid Res 2000;39: 315-391.

21 Hoffman DR, Boettcher JA, Diersen-Schade DA: Toward optimizing vision and cognition in term infants by dietary docosahexaenoic and arachidonic acid supplementation: a review of randomized controlled trials. Prostaglandins Leukot Essent Fatty Acids 2009;81: 151-158.

22 Innis SM: Dietary (n-3) fatty acids and brain development. J Nutr 2007;137:855-859. 
23 He C, Qu X, Cui L, Wang J, Kang JX: Improved spatial learning performance of fat- 1 mice is associated with enhanced neurogenesis and neuritogenesis by docosahexaenoic acid. Proc Natl Acad Sci USA 2009;106: 11370-11375.

24 Katakura M, Hashimoto M, Shahdat HM, Gamoh S, Okui T, Matsuzaki K, Shido O: Docosahexaenoic acid promotes neuronal differentiation by regulating basic helixloop-helix transcription factors and cell cycle in neural stem cells. Neuroscience 2009; 160:651-660.

25 Cysneiros RM, Ferrari D, Arida RM, Terra VC, de Almeida AC, Cavalheiro EA, Scorza FA: Qualitative analysis of hippocampal plastic changes in rats with epilepsy supplemented with oral omega-3 fatty acids. Epilepsy Behav 2010;17:33-38.

-26 Wu A, Ying Z, Gomez-Pinilla F: Docosahexaenoic acid dietary supplementation enhances the effects of exercise on synaptic plasticity and cognition. Neuroscience 2008; 155:751-759.

-27 Orr SK, Bazinet RP: The emerging role of docosahexaenoic acid in neuroinflammation. Curr Opin Investig Drugs 2008;9:735743.

28 Kang JX, Weylandt KH: Modulation of inflammatory cytokines by omega-3 fatty acids. Subcell Biochem 2008;49:133-143.

-29 Ferrucci L, Cherubini A, Bandinelli S, Bartali B, Corsi A, Lauretani F, Martin A, Andres-Lacueva C, Senin U, Guralnik JM: Relationship of plasma polyunsaturated fatty acids to circulating inflammatory markers. J Clin Endocrinol Metab 2006;91:439-446.

30 Shohami E, Cotev S, Shapira Y: The role of eicosanoids in the development of delayed brain damage. J Basic Clin Physiol Pharmacol 1990;1:203-206.

- 31 Yehuda S, Rabinovitz S, Mostofsky DI: Essential fatty acids are mediators of brain biochemistry and cognitive functions. J Neurosci Res 1999;56:565-570.

- 32 Gamoh S, Hashimoto M, Sugioka K, Shahdat Hossain M, Hata N, Misawa Y, Masumura S: Chronic administration of docosahexaenoic acid improves reference memory-related learning ability in young rats. Neuroscience 1999;93:237-241.

- 33 Carrie I, Smirnova M, Clement M, De JD, Frances H, Bourre JM: Docosahexaenoic acid-rich phospholipid supplementation: effect on behavior, learning ability, and retinal function in control and n-3 polyunsaturated fatty acid deficient old mice. Nutr Neurosci 2002;5:43-52.

-34 Kitajka K, Sinclair AJ, Weisinger RS, Weisinger HS, Mathai M, Jayasooriya AP, Halver JE, Puskas LG: Effects of dietary omega-3 polyunsaturated fatty acids on brain gene expression. Proc Natl Acad Sci USA 2004; 101:10931-10936.
35 Neuringer M, Reisbick S, Janowsky J: The role of n-3 fatty acids in visual and cognitive development: current evidence and methods of assessment. J Pediatr 1994;125:S39-S47.

36 Kitajka K, Puskas LG, Zvara A, Hackler L Jr, Barcelo-Coblijn G, Yeo YK, Farkas T: The role of $n-3$ polyunsaturated fatty acids in brain: modulation of rat brain gene expression by dietary n-3 fatty acids. Proc Natl Acad Sci USA 2002;99:2619-2624.

37 Barcelo-Coblijn G, Kitajka K, Puskas LG, Hogyes E, Zvara A, Hackler L Jr, Farkas T: Gene expression and molecular composition of phospholipids in rat brain in relation to dietary n-6 to n-3 fatty acid ratio. Biochim Biophys Acta 2003;1632:72-79.

38 Bazan NG: Synaptic lipid signaling: significance of polyunsaturated fatty acids and platelet-activating factor. J Lipid Res 2003; 44:2221-2233.

39 DeWille JW, Farmer SJ: Postnatal dietary fat influences mRNAs involved in myelination. Dev Neurosci 1992;14:61-68.

-40 Sun GY, Xu J, Jensen MD, Simonyi A: Phospholipase A2 in the central nervous system: implications for neurodegenerative diseases. J Lipid Res 2004;45:205-213.

41 Chen C, Bazan NG: Lipid signaling: sleep, synaptic plasticity, and neuroprotection. Prostaglandins Other Lipid Mediat 2005;77: 65-76.

42 Breyer RM, Bagdassarian CK, Myers SA, Breyer MD: Prostanoid receptors: subtypes and signaling. Annu Rev Pharmacol Toxicol 2001;41:661-690.

43 Narumiya S, Sugimoto Y, Ushikubi F: Prostanoid receptors: structures, properties, and functions. Physiol Rev 1999; 79:1193-1226.

44 Boie Y, Stocco R, Sawyer N, Slipetz DM, Ungrin MD, Neuschafer-Rube F, Puschel GP, Metters KM, Abramovitz M: Molecular cloning and characterization of the four rat prostaglandin E2 prostanoid receptor subtypes. Eur J Pharmacol 1997;340:227-241.

-45 Sang N, Chen C: Lipid signaling and synaptic plasticity. Neuroscientist 2006;12:425-434.

46 Kitaoka S, Furuyashiki T, Nishi A, Shuto T, Koyasu S, Matsuoka T, Miyasaka M, Greengard P, Narumiya S: Prostaglandin E2 acts on EP1 receptor and amplifies both dopamine D1 and D2 receptor signaling in the striatum. J Neurosci 2007;27:12900-12907.

47 Chen C, Bazan NG: Endogenous PGE2 regulates membrane excitability and synaptic transmission in hippocampal CA1 pyramidal neurons. J Neurophysiol 2005;93:929941.

48 Sang N, Zhang J, Marcheselli V, Bazan NG Chen C: Postsynaptically synthesized prostaglandin E2 (PGE2) modulates hippocampal synaptic transmission via a presynaptic PGE2 EP2 receptor. J Neurosci 2005;25: 9858-9870.

-49 Crawford MA: Essential fatty acids and neurodevelopmental disorder. Adv Exp Med Biol 1992;318:307-314.
50 O'Connor DL, Jacobs J, Hall R, Adamkin D, Auestad N, Castillo M, Connor WE, Connor SL, Fitzgerald K, Groh-Wargo S, Hartmann EE, Janowsky J, Lucas A, Margeson D, Mena P, Neuringer M, Ross G, Singer L, Stephenson T, Szabo J, Zemon V: Growth and development of premature infants fed predominantly human milk, predominantly premature infant formula, or a combination of human milk and premature formula. J Pediatr Gastroenterol Nutr 2003;37:437-446.

51 Young G, Conquer J: Omega-3 fatty acids and neuropsychiatric disorders. Reprod Nutr Dev 2005;45:1-28.

52 Axelrod J: Receptor-mediated activation of phospholipase A2 and arachidonic acid release in signal transduction. Biochem Soc Trans 1990;18:503-507.

53 Martinez M: Tissue levels of polyunsaturated fatty acids during early human development. J Pediatr 1992;120:S129-138.

-54 Lauritzen L, Hansen HS, Jorgensen MH, Michaelsen KF: The essentiality of long chain n-3 fatty acids in relation to development and function of the brain and retina. Prog Lipid Res 2001;40:1-94.

55 Murphy MG: Dietary fatty acids and membrane protein function. J Nutr Biochem 1990;1:68-79.

56 Muskiet FA, Kemperman RF: Folate and long-chain polyunsaturated fatty acids in psychiatric disease. J Nutr Biochem 2006;17: 717-727.

57 Crawford MA, Golfetto I, Ghebremeskel K, Min Y, Moodley T, Poston L, Phylactos A, Cunnane S, Schmidt W: The potential role for arachidonic and docosahexaenoic acids in protection against some central nervous system injuries in preterm infants. Lipids 2003;38:303-315.

58 Chen CT, Green JT, Orr SK, Bazinet RP: Regulation of brain polyunsaturated fatty acid uptake and turnover. Prostaglandins Leukot Essent Fatty Acids 2008;79:85-91.

59 Helland IB, Smith L, Saarem K, Saugstad OD, Drevon CA: Maternal supplementation with very-long-chain $n-3$ fatty acids during pregnancy and lactation augments children's IQ at 4 years of age. Pediatrics 2003;111:e39e44.

60 Birch EE, Garfield S, Hoffman DR, Uauy R, Birch DG: A randomized controlled trial of early dietary supply of long-chain polyunsaturated fatty acids and mental development in term infants. Dev Med Child Neurol 2000;42:174-181.

61 Fedorova I, Hussein N, Di Martino C, Moriguchi T, Hoshiba J, Majchrzak S, Salem N Jr: An n-3 fatty acid deficient diet affects mouse spatial learning in the Barnes circular maze. Prostaglandins Leukot Essent Fatty Acids 2007;77:269-277. 
-62 Jacobson JL, Jacobson SW, Muckle G, Kaplan-Estrin M, Ayotte P, Dewailly E: Beneficial effects of a polyunsaturated fatty acid on infant development: evidence from the Inuit of Arctic Quebec. J Pediatr 2008;152:356364.

63 Coluccia A, Borracci P, Renna G, Giustino A, Latronico T, Riccio P, Carratu MR: Developmental omega-3 supplementation improves motor skills in juvenile-adult rats. Int J Dev Neurosci 2009;27:599-605.

64 Richardson AJ, Ross MA: Fatty acid metabolism in neurodevelopmental disorder: a new perspective on associations between attention-deficit/hyperactivity disorder, dyslexia, dyspraxia and the autistic spectrum. Prostaglandins Leukot Essent Fatty Acids 2000;63: $1-9$.

-65 Kidd PM: Omega-3 DHA and EPA for cognition, behavior, and mood: clinical findings and structural-functional synergies with cell membrane phospholipids. Altern Med Rev 2007;12:207-227.

66 Stevens LJ, Zentall SS, Deck JL, Abate ML, Watkins BA, Lipp SR, Burgess JR: Essential fatty acid metabolism in boys with attentiondeficit hyperactivity disorder. Am J Clin Nutr 1995;62:761-768.

67 Colter AL, Cutler C, Meckling KA: Fatty acid status and behavioural symptoms of attention deficit hyperactivity disorder in adolescents: a case-control study. Nutr J 2008;7:8.

68 Schuchardt JP, Huss M, Stauss-Grabo M, Hahn A: Significance of long-chain polyunsaturated fatty acids (PUFAs) for the development and behaviour of children. Eur J Pediatr 2010;169:149-164.

-69 Burgess JR, Stevens L, Zhang W, Peck L: Long-chain polyunsaturated fatty acids in children with attention-deficit hyperactivity disorder. Am J Clin Nutr 2000;71:327S330 S.

70 Khan MM, Evans DR, Gunna V, Scheffer RE, Parikh VV, Mahadik SP: Reduced erythrocyte membrane essential fatty acids and increased lipid peroxides in schizophrenia at the never-medicated first-episode of psychosis and after years of treatment with antipsychotics. Schizophr Res 2002;58:1-10.

-71 Muller N, Riedel M, Scheppach C, Brandstatter B, Sokullu S, Krampe K, Ulmschneider M, Engel RR, Moller HJ, Schwarz MJ: Beneficial antipsychotic effects of celecoxib add-on therapy compared to risperidone alone in schizophrenia. Am J Psychiatry 2002;159:1029-1034.

72 Schultz ST, Klonoff-Cohen HS, Wingard DL, Akshoomoff NA, Macera CA, Ji M, Bacher C: Breastfeeding, infant formula supplementation, and autistic disorder: The results of a parent survey. Int Breastfeed J 2006;1:16.

73 Vancassel S, Durand G, Barthelemy C, Lejeune B, Martineau J, Guilloteau D, Andres C, Chalon S: Plasma fatty acid levels in autistic children. Prostaglandins Leukot Essent Fatty Acids 2001;65:1-7.
74 Mostafa GA, El-Hadidi ES, Hewedi DH, Abdou MM: Oxidative stress in Egyptian children with autism: relation to autoimmunity. J Neuroimmunol 2010;219:114-118.

75 Wiest MM, German JB, Harvey DJ, Watkins SM, Hertz-Picciotto I: Plasma fatty acid profiles in autism: a case-control study. Prostaglandins Leukot Essent Fatty Acids 2009;80: 221-227.

76 Bell JG, Miller D, MacDonald DJ, MacKinlay EE, Dick JR, Cheseldine S, Boyle RM, Graham C, O'Hare AE: The fatty acid compositions of erythrocyte and plasma polar lipids in children with autism, developmental delay or typically developing controls and the effect of fish oil intake. Br J Nutr 2010;103: 1160-1167.

77 Sliwinski S, Croonenberghs J, Christophe A, Deboutte D, Maes M: Polyunsaturated fatty acids: do they have a role in the pathophysiology of autism? Neuro Endocrinol Lett 2006; 27:465-471

78 Pastural E, Ritchie S, Lu Y, Jin W, Kavianpour A, Khine Su-Myat K, Heath D, Wood PL, Fisk M, Goodenowe DB: Novel plasma phospholipid biomarkers of autism: mitochondrial dysfunction as a putative causative mechanism. Prostaglandins Leukot Essent Fatty Acids 2009;81:253-264.

79 MacFabe DF, Cain DP, Rodriguez-Capote K, Franklin AE, Hoffman JE, Boon F, Taylor AR, Kavaliers M, Ossenkopp KP: Neurobiological effects of intraventricular propionic acid in rats: possible role of short chain fatty acids on the pathogenesis and characteristics of autism spectrum disorders. Behav Brain Res 2007;176:149-169.

80 Shultz SR, Macfabe DF, Martin S, Jackson J, Taylor R, Boon F, Ossenkopp KP, Cain DP: Intracerebroventricular injections of the enteric bacterial metabolic product propionic acid impair cognition and sensorimotor ability in the Long-Evans rat: further development of a rodent model of autism. Behav Brain Res 2009;200:33-41.

81 Shultz SR, MacFabe DF, Ossenkopp KP, Scratch S, Whelan J, Taylor R, Cain DP: Intracerebroventricular injection of propionic acid, an enteric bacterial metabolic endproduct, impairs social behavior in the rat: implications for an animal model of autism. Neuropharmacology 2008;54:901-911.

82 Thomas RH, Foley KA, Mepham JR, Tichenoff LJ, Possmayer F, MacFabe DF: Altered brain phospholipid and acylcarnitine profiles in propionic acid infused rodents: further development of a potential model of autism spectrum disorders. J Neurochem 2010; 113:515-529

83 Amminger GP, Berger GE, Schafer MR, Klier C, Friedrich $\mathrm{MH}$, Feucht M: Omega-3 fatty acids supplementation in children with autism: a double-blind randomized, placebocontrolled pilot study. Biol Psychiatry 2007; 61:551-553.
84 Filipek PA, Juranek J, Nguyen MT, Cummings C, Gargus JJ: Relative carnitine deficiency in autism. J Autism Dev Disord 2004; 34:615-623.

$>85$ Ma DQ, Cuccaro ML, Jaworski JM, Haynes CS, Stephan DA, Parod J, Abramson RK, Wright HH, Gilbert JR, Haines JL, PericakVance MA: Dissecting the locus heterogeneity of autism: significant linkage to chromosome 12q14. Mol Psychiatry 2007;12:376384.

86 Brookes KJ, Chen W, Xu X, Taylor E, Asherson P: Association of fatty acid desaturase genes with attention-deficit/hyperactivity disorder. Biol Psychiatry 2006;60:10531061.

87 Schaeffer L, Gohlke H, Muller M, Heid IM, Palmer LJ, Kompauer I, Demmelmair H, Illig T, Koletzko B, Heinrich J: Common genetic variants of the FADS1 FADS2 gene cluster and their reconstructed haplotypes are associated with the fatty acid composition in phospholipids. Hum Mol Genet 2006;15: 1745-1756.

$>88$ Fallin MD, Lasseter VK, Wolyniec PS, McGrath JA, Nestadt G, Valle D, Liang KY, Pulver AE: Genomewide linkage scan for bipolar-disorder susceptibility loci among Ashkenazi Jewish families. Am J Hum Genet 2004;75:204-219.

89 Murakami M, Kudo I: Phospholipase A2. J Biochem 2002;131:285-292.

90 Green JT, Orr SK, Bazinet RP: The emerging role of group VI calcium-independent phospholipase A2 in releasing docosahexaenoic acid from brain phospholipids. J Lipid Res 2008;49:939-944.

91 Massicotte G: Modification of glutamate receptors by phospholipase A2: its role in adaptive neural plasticity. Cell Mol Life Sci 2000; 57:1542-1550.

-92 Marin P, Hamon B, Glowinski J, Premont J: Nicotine-induced inhibition of neuronal phospholipase A2. J Pharmacol Exp Ther 1997;280:1277-1283.

-93 Navamani M, Morgan M, Williams RJ: Ethanol modulates n-methyl-D-aspartate-evoked arachidonic acid release from neurones. Eur J Pharmacol 1997;340:27-34.

94 Williams RJ, Glowinski J: Cyclothiazide unmasks an AMPA-evoked release of arachidonic acid from cultured striatal neurones. J Neurochem 1996;67:1551-1558.

$\checkmark 95$ Farooqui AA, Horrocks LA, Farooqui T: Modulation of inflammation in brain: a matter of fat. J Neurochem 2007;101:577-599.

96 Horrobin DF, Bennett CN: New gene targets related to schizophrenia and other psychiatric disorders: enzymes, binding proteins and transport proteins involved in phospholipid and fatty acid metabolism. Prostaglandins Leukot Essent Fatty Acids 1999;60:141-167.

97 Fenton WS, Hibbeln J, Knable M: Essential fatty acids, lipid membrane abnormalities, and the diagnosis and treatment of schizophrenia. Biol Psychiatry 2000;47:8-21. 
98 Smesny S, Kinder D, Willhardt I, Rosburg T, Lasch J, Berger G, Sauer H: Increased calcium-independent phospholipase A2 activity in first but not in multiepisode chronic schizophrenia. Biol Psychiatry 2005;57: 399-405.

-99 Gattaz WF, Kollisch M, Thuren T, Virtanen JA, Kinnunen PK: Increased plasma phospholipase-A2 activity in schizophrenic patients: reduction after neuroleptic therapy. Biol Psychiatry 1987;22:421-426.

100 Wei J, Lee KH, Hemmings GP: Is the cPLA2 gene associated with schizophrenia? Mol Psychiatry 1998;3:480-481.

-101 Peet M, Ramchand CN, Lee J, Telang SD, Vankar GK, Shah S, Wei J: Association of the Ban I dimorphic site at the human cytosolic phospholipase A2 gene with schizophrenia. Psychiatr Genet 1998;8:191-192.

- 102 Pae CU, Yu HS, Lee KU, Kim JJ, Lee CU, Lee SJ, Jun TY, Lee C, Paik IH: BanI polymorphism of the cytosolic phospholipase A2 gene may confer susceptibility to the development of schizophrenia. Prog Neuropsychopharmacol Biol Psychiatry 2004;28: 739-741.

-103 Tao R, Yu Y, Zhang X, Guo Y, Shi J, Zhang X, Xie L, Liu S, Ju G, Xu Q, Shen Y, Wei J: Cytosolic PLA2 genes possibly contribute to the etiology of schizophrenia. Am J Med Genet B Neuropsychiatr Genet 2005; 137B:56-58.

-104 Meyer AH, Schmuck K, Morel C, Wishart W, Lubbert H, Engels P: Localization of a gene coding for the phospholipase A2-L subtype (PLA2L) to human chromosome 8q24-qter. Genomics 1996;38:435-437.

105 Kudo I, Murakami M: Phospholipase A2 enzymes. Prostaglandins Other Lipid Mediat 2002;68-69:3-58.

-106 Combi R, Redaelli S, Beghi M, Clerici M, Cornaggia CM, Dalpra L: Clinical and genetic evaluation of a family showing both autism and epilepsy. Brain Res Bull 2010;82: 25-28.

-107 Chen GK, Kono N, Geschwind DH, Cantor RM: Quantitative trait locus analysis of nonverbal communication in autism spectrum disorder. Mol Psychiatry 2006;11: 214-220.

108 Lai CS, Fisher SE, Hurst JA, Levy ER, Hodg son S, Fox M, Jeremiah S, Povey S, Jamison DC, Green ED, Vargha-Khadem F, Monaco AP: The SPCH1 region on human 7q31: genomic characterization of the critical interval and localization of translocations associated with speech and language disorder. Am J Hum Genet 2000;67:357-368.

-109 Bell JG, Miller D, MacDonald DJ, MacKinlay EE, Dick JR, Cheseldine S, Boyle RM, Graham C, O'Hare AE: The fatty acid compositions of erythrocyte and plasma polar lipids in children with autism, developmental delay or typically developing controls and the effect of fish oil intake. Br J Nutr 2010;103:1160-1167.
110 Marty V, El Hachmane M, Amedee T: Dual modulation of synaptic transmission in the nucleus tractus solitarius by prostaglandin E2 synthesized downstream of IL-1beta. Eur J Neurosci 2008;27:3132-3150.

111 Yang H, Chen C: Cyclooxygenase-2 in synaptic signaling. Curr Pharm Des 2008;14: 1443-1451.

112 Chen C, Magee JC, Bazan NG: Cyclooxygenase-2 regulates prostaglandin E2 signaling in hippocampal long-term synaptic plasticity. J Neurophysiol 2002;87:28512857.

113 Smith HS: Arachidonic acid pathways in nociception. J Suppor Oncol 2006;4:277287.

114 Pepicelli O, Fedele E, Berardi M, Raiteri M, Levi G, Greco A, Ajmone-Cat MA, Minghetti L: Cyclo-oxygenase-1 and -2 differently contribute to prostaglandin E2 synthesis and lipid peroxidation after in vivo activation of n-methyl-D-aspartate receptors in rat hippocampus. J Neurochem 2005;93:1561-1567.

-115 Benvenuto A, Manzi B, Alessandrelli R, Galasso C, Curatolo P: Recent advances in the pathogenesis of syndromic autisms. Int J Pediatr 2009;2009:198736.

116 Bezzi P, Carmignoto G, Pasti L, Vesce S, Rossi D, Rizzini BL, Pozzan T, Volterra A: Prostaglandins stimulate calcium-dependent glutamate release in astrocytes. $\mathrm{Na}-$ ture 1998;391:281-285

117 Bezzi P, Volterra A: A neuron-glia signalling network in the active brain. Curr Opin Neurobiol 2001;11:387-394.

118 Zonta M, Sebelin A, Gobbo S, Fellin T, Pozzan T, Carmignoto G: Glutamate-mediated cytosolic calcium oscillations regulate a pulsatile prostaglandin release from cultured rat astrocytes. J Physiol 2003;553: 407-414.

119 Minghetti L: Cyclooxygenase-2 (COX-2) in inflammatory and degenerative brain diseases. J Neuropathol Exp Neurol 2004;63: 901-910.

120 Kim HW, Rapoport SI, Rao JS: Altered arachidonic acid cascade enzymes in postmortem brain from bipolar disorder patients. Mol Psychiatry 2009, Epub ahead of print.

121 Ho L, Pieroni C, Winger D, Purohit DP, Aisen PS, Pasinetti GM: Regional distribution of cyclooxygenase- 2 in the hippocampal formation in Alzheimer's disease. Neurosci Res 1999;57:295-303.

122 Lipsky PE, Brooks P, Crofford LJ, DuBois R, Graham D, Simon LS, van de Putte LB, Abramson SB: Unresolved issues in the role of cyclooxygenase-2 in normal physiologic processes and disease. Arch Intern Med 2000;160:913-920.

123 Ashwood P, Wills S, Van de Water J: The immune response in autism: a new frontier for autism research. J Leukoc Biol 2006;80: $1-15$.
124 Ashwood P, Van de Water J: A review of autism and the immune response. Clin Dev Immunol 2004;11:165-174.

125 Yoo HJ, Cho IH, Park M, Cho E, Cho SC, Kim BN, Kim JW, Kim SA: Association between PTGS2 polymorphism and autism spectrum disorders in Korean trios. Neurosci Res 2008;62:66-69.

126 Kaufmann WE, Worley PF, Taylor CV, Bremer M, Isakson PC: Cyclooxygenase-2 expression during rat neocortical development and in Rett syndrome. Brain Dev 1997;19:25-34.

127 Narumiya S: Prostanoid receptors. Structure, function, and distribution. Ann N Y Acad Sci 1994;744:126-138.

128 Abramovitz M, Adam M, Boie Y, Carriere M, Denis D, Godbout C, Lamontagne S, Rochette C, Sawyer N, Tremblay NM, Belley M, Gallant M, Dufresne C, Gareau Y, Ruel R, Juteau H, Labelle M, Ouimet N, Metters KM: The utilization of recombinant prostanoid receptors to determine the affinities and selectivities of prostaglandins and related analogs. Biochim Biophys Acta 2000; 1483:285-293.

129 Coleman RA, Smith WL, Narumiya S: International union of pharmacology classification of prostanoid receptors: properties, distribution, and structure of the receptors and their subtypes. Pharmacol Rev 1994; 46:205-229.

130 Minami T, Nakano H, Kobayashi T, Sugimoto Y, Ushikubi F, Ichikawa A, Narumiya S, Ito S: Characterization of EP receptor subtypes responsible for prostaglandin E2induced pain responses by use of EP1 and EP3 receptor knockout mice. Br J Pharmacol 2001;133:438-444.

131 Boniface K, Bak-Jensen KS, Li Y, Blumenschein WM, McGeachy MJ, McClanahan TK, McKenzie BS, Kastelein RA, Cua DJ, de Waal Malefyt R: Prostaglandin E2 regulates TH17 cell differentiation and function through cyclic AMP and EP2/EP4 receptor signaling. J Exp Med 2009;206:535-548.

132 Buvanendran A, Kroin JS, Berger RA, Hallab NJ, Saha C, Negrescu C, Moric M, Caicedo MS, Tuman KJ: Upregulation of prostaglandin E2 and interleukins in the central nervous system and peripheral tissue during and after surgery in humans. Anesthesiology 2006;104:403-410.

133 Di Cesare A, Del Piccolo P, Zacchetti D, Grohovaz F: EP2 receptor stimulation promotes calcium responses in astrocytes via activation of the adenylyl cyclase pathway. Cell Mol Life Sci 2006;63:2546-2553.

134 Furuyashiki T, Narumiya S: Roles of prostaglandin E receptors in stress responses. Curr Opin Pharmacol 2009;9:31-38

135 Lazarus M: The differential role of prostaglandin E2 receptors EP3 and EP4 in regulation of fever. Mol Nutr Food Res 2006;50: 451-455. 
136 Burks SR, Wright CL, McCarthy MM: Exploration of prostanoid receptor subtype regulating estradiol and prostaglandin E2 induction of spinophilin in developing preoptic area neurons. Neuroscience 2007;146: 1117-1127.

137 Pastuszak AL, Schuler L, Speck-Martins CE, Coelho KE, Cordello SM, Vargas F, Brunoni D, Schwarz IV, Larrandaburu M, Safattle H, Meloni VF, Koren G: Use of misoprostol during pregnancy and Mobius' syndrome in infants. N Engl J Med 1998; 338:1881-1885.

138 Miller MT, Stromland K, Ventura L, Johansson M, Bandim JM, Gillberg C: Autism associated with conditions characterized by developmental errors in early embryogenesis: a mini review. Int J Dev Neurosci 2005;23:201-219.

- 139 Bandim JM, Ventura LO, Miller MT, Almeida HC, Costa AE: Autism and Mobius sequence: an exploratory study of children in northeastern Brazil. Arq Neuropsiquiatr 2003;61:181-185.

- 140 Schuler L, Pastuszak A, Sanseverino TV, Orioli IM, Brunoni D, Ashton-Prolla P, Silva da Costa F, Giugliani R, Couto AM, Brandao SB, Koren G: Pregnancy outcome after exposure to misoprostol in Brazil: a prospective, controlled study. Reprod Toxicol (Elmsford) 1999;13:147-151.

141 Gonzalez CH, Marques-Dias MJ, Kim CA, Sugayama SM, Da Paz JA, Huson SM, Holmes LB: Congenital abnormalities in Brazilian children associated with misoprostol misuse in first trimester of pregnancy. Lancet 1998;351:1624-1627.

- 142 Gonzalez CH, Vargas FR, Perez AB, Kim CA, Brunoni D, Marques-Dias MJ, Leone CR, Correa Neto J, Llerena Junior JC, de Almeida JC: Limb deficiency with or without Mobius sequence in seven Brazilian children associated with misoprostol use in the first trimester of pregnancy. Am J Med Genet 1993;47:59-64.

- 143 Marques-Dias MJ, Gonzalez CH, Rosemberg S: Mobius sequence in children exposed in utero to misoprostol: neuropathological study of three cases. Birth Defects Res A Clin Mol Teratol 2003;67:1002-1007.

144 Costa SH: Commercial availability of misoprostol and induced abortion in Brazil. Int J Gynaecol Obstet 1998;63(suppl 1):S131S139.

145 Vonkeman HE, van de Laar MA: Nonsteroidal anti-inflammatory drugs: adverse effects and their prevention. Semin Arthritis Rheum 2010;39:294-312.

146 Davies NM, Longstreth J, Jamali F: Misoprostol therapeutics revisited. Pharmacotherapy 2001;21:60-73.

- 147 Gemzell-Danielsson K, Lalitkumar S: Second trimester medical abortion with mifepristone-misoprostol and misoprostol alone: a review of methods and management. Reprod Health Matters 2008;16:162172.

The Neurobiology of Lipid Metabolism in Autism Spectrum Disorders
148 Genest DR, Di Salvo D, Rosenblatt MJ, Holmes LB: Terminal transverse limb defects with tethering and omphalocele in a 17 week fetus following first trimester misoprostol exposure. Clin Dysmorphol 1999;8: 53-58.

149 Tamiji J, Crawford DA: Misoprostol elevates intracellular calcium in neuro-2A cells via protein kinase A. Biochem Biophys Res Commun 2010;399:565-570.

150 Tamiji J, Crawford DA: Prostaglandin $E_{2}$ and misoprostol induce neurite retraction in neuro-2a cells. Biochem Biophys Res Commun 2010;398:450-456.

151 Splawski I, Timothy KW, Sharpe LM, Decher N, Kumar P, Bloise R, Napolitano C, Schwartz PJ, Joseph RM, Condouris K, Tager-Flusberg H, Priori SG, Sanguinetti MC, Keating MT: $\mathrm{Ca}(\mathrm{v}) 1.2$ calcium channel dysfunction causes a multisystem disorder including arrhythmia and autism. Cell 2004; 119:19-31.

152 Splawski I, Timothy KW, Decher N, Kumar P, Sachse FB, Beggs AH, Sanguinetti MC, Keating MT: Severe arrhythmia disorder caused by cardiac l-type calcium channel mutations. Proc Natl Acad Sci U S A 2005; 102:8089-8096; discussion 8086-8088.

153 Splawski I, Yoo DS, Stotz SC, Cherry A, Clapham DE, Keating MT: CACNA1H mutations in autism spectrum disorders. J Biol Chem 2006;281:22085-22091.

154 Barnby G, Abbott A, Sykes N, Morris A, Weeks DE, Mott R, Lamb J, Bailey AJ, Monaco AP: Candidate-gene screening and association analysis at the autism-susceptibility locus on chromosome 16p: evidence of association at GRIN2A and ABAT. Am J Hum Genet 2005;76:950-966.

155 Jamain S, Betancur C, Quach H, Philippe A, Fellous M, Giros B, Gillberg C, Leboyer M, Bourgeron T: Linkage and association of the glutamate receptor 6 gene with autism. Mol Psychiatry 2002;7:302-310.

156 Serajee FJ, Nabi R, Zhong H, Mahbubul Huq AH: Association of INPP1, PIK3CG, and TSC2 gene variants with autistic disorder: implications for phosphatidylinositol signalling in autism. J Med Genet 2003; 40:e119.

157 Krey JF, Dolmetsch RE: Molecular mechanisms of autism: a possible role for $\mathrm{Ca}^{2+}$ signaling. Curr Opin Neurobiol 2007;17:112119 .

158 Oshima H, Oguma K, Du YC, Oshima M: Prostaglandin E2, Wnt, and BMP in gastric tumor mouse models. Cancer Sci 2009; 100: 1779-1785.

159 Ishimoto T, Oshima H, Oshima M, Kai K, Torii R, Masuko T, Baba H, Saya H, Nagano O: CD44+ slow-cycling tumor cell expansion is triggered by cooperative actions of Wnt and prostaglandin E2 in gastric tumorigenesis. Cancer Sci 2010;101:673-678.
160 Goessling W, North TE, Loewer S, Lord AM, Lee S, Stoick-Cooper CL, Weidinger G, Puder M, Daley GQ, Moon RT, Zon LI: Genetic interaction of PGE2 and Wnt signaling regulates developmental specification of stem cells and regeneration. Cell 2009;136:1136-1147.

161 Evans T: Fishing for a Wnt-PGE2 link: betacatenin is caught in the stem cell network. Cell Stem Cell 2009;4:280-282.

162 Gao Q, Xu M, Alander CB, Choudhary S, Pilbeam CC, Raisz LG: Effects of prostaglandin E2 on bone in mice in vivo. Prostaglandins Other Lipid Mediat 2009;89:2025.

163 Howe LR, Subbaramaiah K, Chung WJ, Dannenberg AJ, Brown AM: Transcriptional activation of cyclooxygenase-2 in Wnt-1-transformed mouse mammary epithelial cells. Cancer Res 1999;59:1572-1577.

164 Sanchez-Camacho C, Bovolenta P: Emerging mechanisms in morphogen-mediated axon guidance. Bioessays 2009;31:10131025.

165 Ille F, Sommer L: Wnt signaling: multiple functions in neural development. Cell Mol Life Sci 2005;62:1100-1108.

166 Ciani L, Salinas PC: Wnts in the vertebrate nervous system: from patterning to neuronal connectivity. Nat Rev Neurosci 2005;6: 351-362.

167 Ulloa F, Marti E: Wnt won the war: antagonistic role of Wnt over Shh controls dorsoventral patterning of the vertebrate neural tube. Dev Dyn 2010;239:69-76.

168 Kim D, Jin EJ: Wnt-3 and Wnt-3a plays different region specific role on neural crest development in avian. Cell Biol Int 2010;34: 763-768.

169 Cadigan KM, Nusse R: Wnt signaling: a common theme in animal development. Genes Dev 1997;11:3286-3305.

170 Vincent JB, Herbrick JA, Gurling HM, Bolton PF, Roberts W, Scherer SW: Identification of a novel gene on chromosome $7 \mathrm{q} 31$ that is interrupted by a translocation breakpoint in an autistic individual. Am J Hum Genet 2000;67:510-514.

171 Ashley-Koch A, Wolpert CM, Menold MM, Zaeem L, Basu S, Donnelly SL, Ravan SA, Powell CM, Qumsiyeh MB, Aylsworth AS, Vance JM, Gilbert JR, Wright $\mathrm{HH}$, Abramson RK, DeLong GR, Cuccaro ML, Pericak-Vance MA: Genetic studies of autistic disorder and chromosome 7. Genomics 1999;61:227-236.

172 Wassink TH, Piven J, Vieland VJ, Huang J, Swiderski RE, Pietila J, Braun T, Beck G, Folstein SE, Haines JL, Sheffield VC: Evidence supporting Wnt2 as an autism susceptibility gene. Am J Med Genet 2001;105: 406-413.

173 Sanchez-Camacho C, Rodriguez J, Ruiz JM, Trousse F, Bovolenta P: Morphogens as growth cone signalling molecules. Brain Res Brain Res Rev 2005;49:242-252. 
-174 Tamiji J, Crawford DA: Prostaglandin $\mathrm{E}_{2}$ and misoprostol induce neurite retraction in Neuro-2a cells. Biochem Biophys Res Commun 2010;398:450-456.

175 Tamiji J, Crawford DA: Misoprostol elevates intracellular calcium in Neuro-2a cells via protein kinase A. Biochem Biophys Res Commun 2010;399:565-570.

-176 Wayman GA, Impey S, Marks D, Saneyoshi T, Grant WF, Derkach V, Soderling TR: Activity-dependent dendritic arborization mediated by CAM-kinase I activation and enhanced CREB-dependent transcription of Wnt-2. Neuron 2006;50:897-909.

- 177 Ishimoto T, Oshima H, Oshima M, Kai K, Torii R, Masuko T, Baba H, Saya H, Nagano O: CD44+ slow-cycling tumor cell expansion is triggered by cooperative actions of Wnt and prostaglandin $\mathrm{E}_{2}$ in gastric tumorigenesis. Cancer Sci 2010;101:673-678.

178 Rice D, Barone S Jr: Critical periods of vulnerability for the developing nervous system: evidence from humans and animal models. Environment Health Perspect 2000;108(suppl 3):511-533.

- 179 Courchesne E: Brain development in autism: early overgrowth followed by premature arrest of growth. Ment Retard Dev Disabil Res Rev 2004;10:106-111.

- 180 Courchesne E, Pierce K, Schumann CM, Redcay E, Buckwalter JA, Kennedy DP, Morgan J: Mapping early brain development in autism. Neuron 2007;56:399-413.

- 181 Amaral DG, Schumann CM, Nordahl CW: Neuroanatomy of autism. Trends Neurosci 2008:31:137-145.

182 Sies H: Oxidative stress: oxidants and antioxidants. Exp Physiol 1997;82:291-295.

183 Filomeni G, Ciriolo MR: Redox control of apoptosis: an update. Antioxid Redox Signal 2006;8:2187-2192.

184 Yehuda S, Rabinovitz S, Carasso RL, Mostofsky DI: The role of polyunsaturated fatty acids in restoring the aging neuronal membrane. Neurobiol Aging 2002;23:843853.

185 Tsaluchidu S, Cocchi M, Tonello L, Puri BK: Fatty acids and oxidative stress in psychiatric disorders. BMC psychiatry 2008; 8(suppl 1):S5.

-186 Adibhatla RM, Hatcher JF: Altered lipid metabolism in brain injury and disorders. Subcell Biochem 2008;49:241-268.

- 187 Shulman RG, Rothman DL, Behar KL, Hyder F: Energetic basis of brain activity: implications for neuroimaging. Trends Neurosci 2004;27:489-495.

188 Perry SW, Norman JP, Litzburg A, Gelbard HA: Antioxidants are required during the early critical period, but not later, for neuronal survival. J Neurosci Res 2004;78:485492.
189 Chen P, Peng C, Luff J, Spring K, Watters D, Bottle S, Furuya S, Lavin MF: Oxidative stress is responsible for deficient survival and dendritogenesis in Purkinje neurons from ataxia-telangiectasia mutated mutant mice. J Neurosci 2003;23:11453-11460.

190 Yamashita T, Ando Y, Obayashi K, Terazaki H, Sakashita N, Uchida K, Ohama E, Ando $\mathrm{M}$, Uchino M: Oxidative injury is present in Purkinje cells in patients with olivopontocerebellar atrophy. J Neurol Sci 2000;175: 107-110.

191 Bailey A, Luthert P, Dean A, Harding B, Janota I, Montgomery M, Rutter M, Lantos P: A clinicopathological study of autism. Brain 1998;121:889-905.

192 Ahlsen G, Rosengren L, Belfrage M, Palm A, Haglid K, Hamberger A, Gillberg C: Glial fibrillary acidic protein in the cerebrospinal fluid of children with autism and other neuropsychiatric disorders. Biol Psychiatry 1993;33:734-743

193 Yorbik O, Sayal A, Akay C, Akbiyik DI, Sohmen T: Investigation of antioxidant enzymes in children with autistic disorder. Prostaglandins Leukot Essent Fatty Acids 2002;67:341-343.

-194 Zoroglu SS, Armutcu F, Ozen S, Gurel A, Sivasli E, Yetkin O, Meram I: Increased oxidative stress and altered activities of erythrocyte free radical scavenging enzymes in autism. Eur Arch Psychiatry Clin Neurosci 2004;254:143-147.

195 Aoyama K, Watabe M, Nakaki T: Regulation of neuronal glutathione synthesis. J Pharmacol Sci 2008;108:227-238.

196 Ono H, Sakamoto A, Sakura N: Plasma total glutathione concentrations in healthy pediatric and adult subjects. Clin Chim Acta 2001;312:227-229.

197 James SJ, Melnyk S, Jernigan S, Cleves MA, Halsted CH, Wong DH, Cutler P, Bock K, Boris M, Bradstreet JJ, Baker SM, Gaylor DW: Metabolic endophenotype and related genotypes are associated with oxidative stress in children with autism. Am J Med Genet B Neuropsychiatr Genet 2006; 141B:947-956.

198 James SJ, Rose S, Melnyk S, Jernigan S, Blossom S, Pavliv O, Gaylor DW: Cellular and mitochondrial glutathione redox imbalance in lymphoblastoid cells derived from children with autism. FASEB J 2009;23: 2374-2383.

199 Geier DA, Kern JK, Garver CR, Adams JB, Audhya T, Nataf R, Geier MR: Biomarkers of environmental toxicity and susceptibility in autism. J Neurol Sci 2009;280:101-108.

200 Ming X, Johnson WG, Stenroos ES, Mars A, Lambert GH, Buyske S: Genetic variant of glutathione peroxidase 1 in autism. Brain Dev 2010;32:105-109.

-201 Mutter J, Naumann J, Schneider R, Walach H, Haley B: Mercury and autism: accelerating evidence? Neuro Endocrinol Lett 2005; 26:439-446.
202 Windham GC, Zhang L, Gunier R, Croen LA, Grether JK: Autism spectrum disorders in relation to distribution of hazardous air pollutants in the San Francisco bay area. Environ Health Perspect 2006;114:14381444.

203 Palmer RF, Blanchard S, Wood R: Proximity to point sources of environmental mercury release as a predictor of autism prevalence. Health Place 2009;15:18-24.

204 Valko M, Morris H, Cronin MT: Metals, toxicity and oxidative stress. Curr Med Chem 2005;12:1161-1208.

205 Junaid MA, Kowal D, Barua M, Pullarkat PS, Sklower Brooks S, Pullarkat RK: Proteomic studies identified a single nucleotide polymorphism in glyoxalase I as autism susceptibility factor. Am J Med Genet 2004;131:11-17.

206 Philippe A, Martinez M, Guilloud-Bataille M, Gillberg C, Rastam M, Sponheim E, Coleman M, Zappella M, Aschauer H, Van Maldergem L, Penet C, Feingold J, Brice A, Leboyer M: Genome-wide scan for autism susceptibility genes. Paris Autism Research International Sibpair Study. Hum Mol Genet 1999;8:805-812.

207 Yonan AL, Alarcon M, Cheng R, Magnusson PK, Spence SJ, Palmer AA, Grunn A, Juo SH, Terwilliger JD, Liu J, Cantor RM, Geschwind DH, Gilliam TC: A genomewide screen of 345 families for autism-susceptibility loci. Am J Hum Genet 2003;73: 886-897.

208 El-Ansary A, Al-Daihan S, Al-Dbass A, Al-Ayadhi L: Measurement of selected ions related to oxidative stress and energy metabolism in Saudi autistic children. Clin Biochem 2010;43:63-70.

209 Yao Y, Walsh WJ, McGinnis WR, Pratico D: Altered vascular phenotype in autism: correlation with oxidative stress. Arch Neurol 2006;63:1161-1164.

210 De Felice C, Ciccoli L, Leoncini S, Signorini C, Rossi M, Vannuccini L, Guazzi G, Latini G, Comporti M, Valacchi G, Hayek J: Systemic oxidative stress in classic Rett syndrome. Free Radic Biol Med 2009;47:440448.

211 Pratico D, Lawson JA, Rokach J, FitzGerald GA: The isoprostanes in biology and medicine. Trends Endocrinol Metab 2001;12: 243-247.

212 Safai-Kutti S, Kutti J, Gillberg C: Impaired in vivo platelet reactivity in infantile autism. Acta Paediatr Scand 1985;74:799800 .

213 Safai-Kutti S, Denfors I, Kutti J, Wadenvik $\mathrm{H}$ : In vitro platelet function in infantile autism. Folia Haematol Int Mag Klin Morphol Blutforsch 1988;115:897-901.

214 Lucas SM, Rothwell NJ, Gibson RM: The role of inflammation in CNS injury and disease. Br J Pharmacol 2006;147(suppl 1):S232-S240 
-215 Patterson PH: Immune involvement in schizophrenia and autism: etiology, pathology and animal models. Behav Brain Res 2009;204:313-321.

-216 Shi L, Smith SE, Malkova N, Tse D, Su Y, Patterson PH: Activation of the maternal immune system alters cerebellar development in the offspring. Brain Behav Immun 2009;23:116-123.

-217 Shi L, Fatemi SH, Sidwell RW, Patterson PH: Maternal influenza infection causes marked behavioral and pharmacological changes in the offspring. J Neurosci 2003; 23:297-302.

-218 Machado ER, Carlos D, Lourenco EV, Souza GE, Sorgi CA, Silva EV, Ueta MT, Ramos SG, Aronoff DM, Faccioli LH: Cyclooxygenase-derived mediators regulate the immunological control of Strongyloides venezuelensis infection. FEMS Immunol Med Microbiol 2010;59:18-32.

-219 Franco L, Talamini G: Cross-talk between inducible nitric oxide synthase and cyclooxygenase in Helicobacter-pylori-induced gastritis. Med Princ Pract 2009; 18:477-481.

-220 Chen D, Wei Y, Li X, Epstein S, Wolosin JM, Asbell P: Spla2-IIA is an inflammatory mediator when the ocular surface is compromised. Exp Eye Res 2009;88:880-888.

-221 Figuero E, Carrillo-de-Albornoz A, Herrera D, Bascones-Martinez A: Gingival changes during pregnancy. I. Influence of hormonal variations on clinical and immunological parameters. J Clin Periodontol 2010;37:220-229.

-222 Christiaens I, Zaragoza DB, Guilbert L, Robertson SA, Mitchell BF, Olson DM: Inflammatory processes in preterm and term parturition. J Reprod Immunol 2008;79: 50-57.

-223 Aisemberg J, Vercelli C, Wolfson M, Salazar AI, Osycka-Salut C, Billi S, Ribeiro ML, Farina M, Franchi AM: Inflammatory agents involved in septic miscarriage. Neuroimmunomodulation 2010;17:150-152.

-224 Libbey JE, Sweeten TL, McMahon WM, Fujinami RS: Autistic disorder and viral infections. J Neurovirol 2005;11:1-10.

-225 Comi AM, Zimmerman AW, Frye VH, Law PA, Peeden JN: Familial clustering of autoimmune disorders and evaluation of medical risk factors in autism. J Child Neurol 1999; 14:388-394.

-226 Enstrom AM, Van de Water JA, Ashwood P: Autoimmunity in autism. Curr Opin Investig Drugs 2009;10:463-473.

-227 Licinio J, Alvarado I, Wong ML: Autoimmunity in autism. Mol Psychiatry 2002;7: 329.

-228 Li X, Chauhan A, Sheikh AM, Patil S, Chauhan V, Li XM, Ji L, Brown T, Malik M: Elevated immune response in the brain of autistic patients. J Neuroimmunol 2009; 207:111-116.
229 Enstrom A, Krakowiak P, Onore C, Pessah IN, Hertz-Picciotto I, Hansen RL, Van de Water JA, Ashwood P: Increased IgG4 levels in children with autism disorder. Brain Behav Immun 2009;23:389-395.

230 Kawashti MI, Amin OR, Rowehy NG: Possible immunological disorders in autism: concomitant autoimmunity and immune tolerance. Egypt J Immunol 2006;13:99104.

231 Meyer U, Nyffeler M, Engler A, Urwyler A, Schedlowski M, Knuesel I, Yee BK, Feldon $\mathrm{J}$ : The time of prenatal immune challenge determines the specificity of inflammation-mediated brain and behavioral pathology. J Neurosci 2006;26:4752-4762.

232 Parker-Athill EC, Tan J: Maternal immune activation and autism spectrum disorder: interleukin- 6 signaling as a key mechanistic pathway. Neurosignals 2010, Epub ahead of print.

233 Atladottir HO, Thorsen P, Ostergaard L, Schendel DE, Lemcke S, Abdallah M, Parner ET: Maternal infection requiring hospitalization during pregnancy and autism spectrum disorders. J Autism Dev Disord 2010;40:1423-1430.

234 Singh VK, Jensen RL: Elevated levels of measles antibodies in children with autism. Pediatr Neurol 2003;28:292-294.

235 Chess S: Follow-up report on autism in congenital rubella. J Autism Child Schizophr 1977;7:69-81

236 DeLong GR, Bean SC, Brown FR 3rd: Acquired reversible autistic syndrome in acute encephalopathic illness in children. Arch Neurol 1981;38:191-194.

237 Yamashita Y, Fujimoto C, Nakajima E, Isagai T, Matsuishi T: Possible association between congenital cytomegalovirus infection and autistic disorder. J Autism Dev Disord 2003;33:455-459.

238 Engman ML, Lewensohn-Fuchs I, Mosskin M, Malm G: Congenital cytomegalovirus infection: the impact of cerebral cortical malformations. Acta Paediatr 2010;99: 1344-1349.

239 Lintas C, Altieri L, Lombardi F, Sacco R, Persico AM: Association of autism with polyomavirus infection in postmortem brains. J Neurovirol 2010;16:141-149.

240 Fatemi SH, Pearce DA, Brooks AI, Sidwell RW: Prenatal viral infection in mouse causes differential expression of genes in brains of mouse progeny: a potential animal model for schizophrenia and autism. Synapse 2005;57:91-99.

241 Fatemi SH, Reutiman TJ, Folsom TD, Huang H, Oishi K, Mori S, Smee DF, Pearce DA, Winter C, Sohr R, Juckel G: Maternal infection leads to abnormal gene regulation and brain atrophy in mouse offspring: implications for genesis of neurodevelopmental disorders. Schizophr Res 2008;99:5670 .
242 Ponzio NM, Servatius R, Beck K, Marzouk A, Kreider T: Cytokine levels during pregnancy influence immunological profiles and neurobehavioral patterns of the offspring. Ann N Y Acad Sci 2007;1107:118128.

243 Hornig M, Weissenbock H, Horscroft N, Lipkin WI: An infection-based model of neurodevelopmental damage. Proc Natl Acad Sci USA 1999;96:12102-12107.

244 Fatemi SH, Halt AR, Realmuto G, Earle J, Kist DA, Thuras P, Merz A: Purkinje cell size is reduced in cerebellum of patients with autism. Cell Mol Neurobiol 2002;22: 171-175.

245 Courchesne E, Carper R, Akshoomoff N: Evidence of brain overgrowth in the first year of life in autism. JAMA 2003;290:337344.

246 Boddaert N, Zilbovicius M, Philipe A, Robel L, Bourgeois M, Barthelemy C, Seidenwurm D, Meresse I, Laurier L, Desguerre I, Bahi-Buisson N, Brunelle F, Munnich A, Samson Y, Mouren MC, Chabane N: MRI findings in 77 children with non-syndromic autistic disorder. PLoS One 2009;4:e4415.

-247 Brock TG, Peters-Golden M: Activation and regulation of cellular eicosanoid biosynthesis. ScientificWorldJournal 2007;7: 1273-1284.

248 Wall R, Ross RP, Fitzgerald GF, Stanton C: Fatty acids from fish: the anti-inflammatory potential of long-chain omega-3 fatty acids. Nutr Rev 2010;68:280-289.

249 Legler DF, Bruckner M, Uetz-von Allmen E, Krause P: Prostaglandin E2 at new glance: novel insights in functional diversity offer therapeutic chances. Int J Biochem Cell Biol 2010;42:198-201.

250 Calder PC: Immunomodulation by omega-3 fatty acids. Prostaglandins Leukot Essent Fatty Acids 2007;77:327-335.

251 Yao C, Sakata D, Esaki Y, Li Y, Matsuoka T, Kuroiwa K, Sugimoto Y, Narumiya S: Prostaglandin E2-EP4 signaling promotes immune inflammation through TH1 cell differentiation and TH17 cell expansion. Nat Med 2009;15:633-640.

-252 Harris SG, Padilla J, Koumas L, Ray D, Phipps RP: Prostaglandins as modulators of immunity. Trends Immunol 2002;23: 144-150.

-253 Croonenberghs J, Wauters A, Devreese K, Verkerk R, Scharpe S, Bosmans E, Egyed B, Deboutte D, Maes M: Increased serum albumin, gamma globulin, immunoglobulin IgG, and IgG2 and IgG4 in autism. Psychol Med 2002;32:1457-1463.

254 Trajkovski V, Ajdinski L, Spiroski M: Plasma concentration of immunoglobulin classes and subclasses in children with autism in the Republic of Macedonia: retrospective study. Croat Med J 2004;45:746749. 
255 Singh VK: Plasma increase of interleukin-12 and interferon-gamma. Pathological significance in autism. J Neuroimmunol 1996;66:143-145.

-256 Jyonouchi H, Sun S, Itokazu N: Innate immunity associated with inflammatory responses and cytokine production against common dietary proteins in patients with autism spectrum disorder. Neuropsychobiology 2002;46:76-84.

257 Jyonouchi H, Geng L, Ruby A, Zimmerman-Bier B: Dysregulated innate immune responses in young children with autism spectrum disorders: their relationship to gastrointestinal symptoms and dietary intervention. Neuropsychobiology 2005;51: 77-85.

258 Jyonouchi H, Sun S, Le H: Proinflammatory and regulatory cytokine production associated with innate and adaptive immune responses in children with autism spectrum disorders and developmental regression. J Neuroimmunol 2001;120:170179.
259 Croonenberghs J, Bosmans E, Deboutte D, Kenis G, Maes M: Activation of the inflammatory response system in autism. Neuropsychobiology 2002;45:1-6.

260 Lee RH, Mills EA, Schwartz N, Bell MR, Deeg KE, Ruthazer ES, Marsh-Armstrong N, Aizenman CD: Neurodevelopmental effects of chronic exposure to elevated levels of pro-inflammatory cytokines in a developing visual system. Neural Dev 2010;5:2.

261 Chez MG, Dowling T, Patel PB, Khanna P, Kominsky M: Elevation of tumor necrosis factor-alpha in cerebrospinal fluid of autistic children. Pediatr Neurol 2007;36:361365

262 Vargas DL, Nascimbene C, Krishnan C Zimmerman AW, Pardo CA: Neuroglial activation and neuroinflammation in the brain of patients with autism. Ann Neurol 2005;57:67-81.
263 Kim IJ, Beck HN, Lein PJ, Higgins D: Interferon gamma induces retrograde dendritic retraction and inhibits synapse formation. J Neurosci 2002;22:4530-4539.

264 Raymond GV, Bauman ML, Kemper TL: Hippocampus in autism: a Golgi analysis. Acta Neuropathol 1996;91:117-119.

265 Ashwood P, Anthony A, Torrente F, Wakefield AJ: Spontaneous mucosal lymphocyte cytokine profiles in children with autism and gastrointestinal symptoms: mucosal immune activation and reduced counter regulatory interleukin-10. J Clin Immunol 2004;24:664-673.

266 Ashwood P, Wakefield AJ: Immune activation of peripheral blood and mucosal CD3+ lymphocyte cytokine profiles in children with autism and gastrointestinal symptoms. J Neuroimmunol 2006;173:126-134.

267 White JF: Intestinal pathophysiology in autism. Exp Biol Med (Maywood) 2003;228: 639-649. 